\title{
Cointegral Crystalization Of Triple Bottom Financial Reports And The Performance Of Hydrocarbon Companies
}

BY

Sunday A. Effiong*

Department of Accounting, Faculty of Management Sciences, University of Calabar, P.M.B. 1115, Calabar, Cross River State, Nigeria.

drsunnyeffi@yahoo.com

\begin{abstract}
Ahakiri, F. Idiege
Department of Accounting, Faculty of Management Sciences, University of Calabar, P.M.B. 1115, Calabar, Cross River State, Nigeria. ahakirifrancis.1@gmail.com
\end{abstract}

Fadenipo A. Adesola

Department of Accounting, Faculty of Management Sciences, University of Calabar, P.M.B. 1115, Calabar, Cross River State, Nigeria. horshinaiki@yahoo.com

$\&$

\section{Okoi, John Obono.}

Department of Accounting, Faculty of Management Sciences, University of Calabar, P.M.B. 1115, Calabar, Cross River State, Nigeria. Johnokoi75@gmail.com

* Corresponding author's contact: $\underline{d r s u n n y e f f i @ y a h o o . c o m ~, ~+2348037115127 ~}$ ABSTRACT 
The study considered the co-integral consequences of Triple Bottom Line financial reports of listed hydrocarbon companies on their financial outlooks. It was conducted to evaluate the crystalized correlation of responsible hydrocarbon companies on their financial fortunes. In simple terms, the research looked for answers to the question of whether it is financially worthwhile for corporate citizens to be responsible. The study employed the expos facto design where secondary data were obtained from the annual reports of the listed hydrocarbon companies on the floor of the Nigerian Stock Exchange. The least-square multiple linear regression analysis methods were employed to establish the degree of financial crystallization consequential to the adoption of the triple bottom reporting format. Social, economic, and environmental reports of the studied listed hydrocarbon companies were co-integrated with the returns on assets of the companies, to establish the level of crystallization of the explanatory variables with the response variable. The crystallized results revealed that economic disclosure and environmental disclosure have limited significant crystallization characteristics on the returns on assets, while social disclosure showed significantly positive crystallization characteristics with returns on assets of the studied companies. Arising from these findings, therefore, the study recommended that a mandatory reporting framework be put in place for hydrocarbon companies listed on the floor of the Nigerian Stock Exchange to encourage sustainability reporting.

Keywords: Triple Bottom Reports; performance; environmental disclosure; social disclosure; economic disclosure; returns on assets; co-integral crystallization 


\subsection{Introduction}

Triple bottom line reporting is a major reporting issue present in the financial reporting circle, especially amongst environmentally exposed companies, and it has gained prominence across the globe. Triple bottom reports are often re-coined as "environmental accounting reports or ecological accounting reports". It is a concept that crystallizes the social, economic, and environmental footprints of the organization on their operating environments, (Effiong, Oti \& Akpan, 2019). Before this present realization, firms only emphasize their economic bottom line (profits and shareholder values), triple bottom line reports go beyond the regular economic measurement of profits and shareholders' specific interests (value), to social and environmental dimensions. It encompasses the traditional bottom lines of red and black to include green reports. Corporate social reporting requires that a firm should look beyond the economic bottom line, and provide details about the non-monetary aspects of their business operations as well. Many have considered the non-monetary aspect of the firm as more focused and more encompassing, in the long run, than the monetary or financial information alone as performance measures, which are considered as short-term focused. Triple Bottom line has come to be broadly accepted in its present sense after it first appeared in the UN report of 1987, presented by Norway's former prime minister, Harlem Brundtland, who defined sustainable development as the development that meets the needs of the present without jeopardizing the ability of the future generation to meet their own needs (Brundland, 1987). Triple Bottom Reporting emphasizes that while focusing on the financial aspect of the business, going concern should also take into consideration the social aspect as well as the environment. It implores firms into taking cognizance of the importance of the environment and the need to protect it so as not to deplete the resources. Triple Bottom line reporting emphasizes, sustainability reporting, which borders on economic, environmental, and social, as it is commonly called, and has now been introduced 
as a reporting focus for firms internationally, emphasizing the goals of achieving a sustainable economy, a sustainable society, and a sustainable environment (Hong, Fabio \& Thiago, 2014). Atu and Osarentin, (2016), assert that a firm that does not focus on sustainability may find it difficult to sell products in the future; they may be unable to supply or customers may not patronize them. Therefore, to sustain the marketplace, firms will have to take cognizance of the triple dimensions of reporting which are social reporting, environmental reporting, and economic reporting. Currently, firms now believe that a focus on social welfare and environmental protection impacts positively on the organization in the long run. As firms strive to be regarded as legitimate, they have now realized that it is no longer sufficient to concentrate on the financial side of their businesses alone. Markets are becoming progressively more driven and competitive, and the rate of transformation is placing firms under pressure in not only succeeding but maintaining and keeping up their success into the future (Uwuigbe \& Uadiale, 2018).

Many firms now produce sustainability reports annually, which are meant to be channels of transparency and accountability, thus providing the tool for determining the quality of corporate governance in the firms. These reports are intended to persuade investors, engage stakeholders, and advance internal processes (Isa, 2014). As a result of corporate social reporting, and to guarantee social and ecological information, the Global Reporting Index (GRI) was formed to provide directions to firms' accounting on sustainability.

In November 2018, the Sustainable Development Goals (SDGs) guideline was approved in Nigeria by SEC. It also defined a gradual method to integrating and harmonizing sustainability into firms, measures to be observed in reporting and disclosing, (Uwuigbe \& Uadiale, 2018). The guidelines provide some admonitions for good practices in 13 areas under four core principles in Environmental, Social, and Governance (ESG) reporting (Deegan, 2018). The SEC approved the 
Guidelines on 9 November 2018 and it became effective on January 1,2019, and are mandatory for companies listed on the Exchange.

Understanding this consciousness, this research set out to critically examine the co-integral crystallization influence of the sustainable reporting constructs on the returns on assets of the twelve (12) quoted hydrocarbon companies on the Nigerian Stock Exchange. The performance here signals the companies' policies and operations, in terms of financial outcomes. It is the process of measuring a company's policies and operations on a monetary basis. In this study, the performance variable was limited to ROA (returns on asset) which was co-integrated with and crystalized by the triple bottom constructs of economic, social, and environmental disclosures.

\subsection{Legitimacy Theory:}

Legitimacy theory, first defined by Dowling \& Pfeffer in 1975, asserts that there is a contract between a firm and the society which requires that the firm discloses its activities because it is the obligation of the firm to the society to disclose these activities (Chikwendu, Okafor, \& Jesuwunmi, 2019). The theory stresses that the firm must present itself as protecting the interest and rights of the public and not limiting its interest to the financiers and that failure to conform to these expectations by the firm from the society may lead to sanctions being enforced by the society (Chikwendu, et al, 2019).

\subsection{Stakeholders' Theory:}

Defined in 1984 by Freeman, it describes how management can satisfy the concern of stakeholders in an organization. Stakeholders are persons directly or indirectly affected by the accomplishment of the company's objectives, (Chikwendu, et al, 2019). Freeman (2009), asserts that a successful business cannot exist in isolation. It necessitates that there be investors to invest and give them money, customers to purchase their finished goods and services, employees to 
attend to the customers, suppliers to sell them the raw materials, and a community within which they can succeed. If any one of these groups is absent, the industry cannot succeed (Chikwendu, et al, 2019).

\subsection{Social Contract Theory:}

This theory was adopted from research by (Effiong, et al, 2017), where the proponent believed that individuals and the larger society understood that the legal establishment of a company is for reciprocal rewards. The company utilizes environmental resources and engages individuals as employees, hence corresponding rewards to the society in terms of wages, development/medical care and evacuation of hazards, etc. (Effiong, et al, 2017). This theory reinforces the necessity for triple bottom line reports disclosures.

\subsection{Returns on assets.}

As a measure of corporate financial performance, returns on asset (ROA) is a profitability ratio that measures the operating success or financial outcome of a company. Return on asset measures the contribution of a business in relation to its assets. It indicates the resourceful application of inputs in generating earnings (Deegan, 2018; Oti, Effiong, \& Arzizeh, (2012). The formula of ROA is given as ROA $=$ Net Income/Total asset $* 100$.

\subsection{Dimensions of Triple Bottom Line Reports}

There is no universally agreed pattern of the triple bottom reporting approach. There are, however, pertinent elements of sustainability applicability of Economic, Social, and Environmental disclosures in every sustainability report. The triple bottom line approach is a reporting concern that embraces economic or financial benefits, environmental protection as well as social and individual human well-being, (Effiong, Okare, \& Udama, 2017). From the views and perspectives of scholars, Triple Bottom Line Reporting can be defined to mean an 
Accounting and Ethical reporting concept that acknowledges and embraces Social human rewarding and Environmental impact in addition to the traditional economic benefit for the sustainability of businesses, (Oti, Effiong, \& Akpan, 2017).

\subsubsection{Economic Dimension:}

The economic perspective of sustainability reporting is the impact the firm's practices have on the fiscal system (Elkington, 2004). It relates to the capability of the economy to not just survive, but continue to assist future generations. It crystallizes the firms with economic growth, (Ijeoma, 2014). The first component of TBL reporting its economic bottom line. This has to do with the impacts of corporate activities on the economic conditions of stakeholders and economic systems. This also involves the analysis of how the companies' stakeholders are directly and indirectly affected by these companies' commercial activities. According to GRI (2015), as cited by Effiong, Oti, \& Akpan, (2019) key performance indicators under this performance dimension include revenue generated and operating cost, payment to capital providers, policies and practices involving and in connections with local suppliers, the procedure for local hiring, proportion of senior management hired from local communities, etc.

\subsubsection{Environmental dimension}

The environmental dimension comprises impacts relating to inputs such as water, energy, land use, and outputs such as waste, emissions, and effluents. Similarly, it covers pollution, natural resources, biodiversity, and in addition, environmental compliance expenditures. To lessen the impact of its activities on the environment, the Nigerian Stock Exchange considers it vital to reduce natural resource use, enhance efficiency, decrease waste, and recycling where possible (Deegan, 2018). The environmental bottom line is the second component of this tripartite reporting framework. It has to do with organization impacts on the living and non-living natural systems. It is also concerned with the input/output mode of organizational impacts on the 
environment. Input has to do with the material consumption and output has to do with the end products and waste emissions, (Effiong, Oti, \& Akpan, 2019). Sustainability has its major focus on the environment, which is why sustainability is defined as the ability of the company to continue to exist and conduct business operations with no effects on the environment that cannot be offset or made good in some other way. Going beyond input-output co-integration, companies that subscribe to TBL ideology have a legitimate desire to see the environment improve as a result of their business operations. This set of companies also try to reduce their ecological footprint by carefully managing the consumption of non-renewable energy. Key performance indicators under the environmental performance dimension include material consumption by weight or volume, percentage of material recycled, energy consumption footprint, emission, effluent and waste, environmental management systems, etc., (Effiong, Oti, \& Akpan, 2019).

\subsubsection{Social Dimension}

The third component of TBL is the social bottom line and this has to do with the disclosures of the impacts of corporate activities on social systems within which the companies operate. According to Effiong, Oti, \& Akpan, 2019), companies that focus on the social bottom line paradigm are often compensated with retention of a competitive workforce and decreased employee turnover. The social performance dimension is described as a set of outcomes that improve the company and in the end lead to the creation of value since it affects all the interest groups as well as the whole value chain. Key performance indicators under this bottom line include disclosures on labor practices and decent work, human rights, society, product responsibilities, etc., (Effiong, Oti, \& Akpan, 2019). 


\section{ORGANOGRAM OF CONCEPTUAL FRAMEWORK}
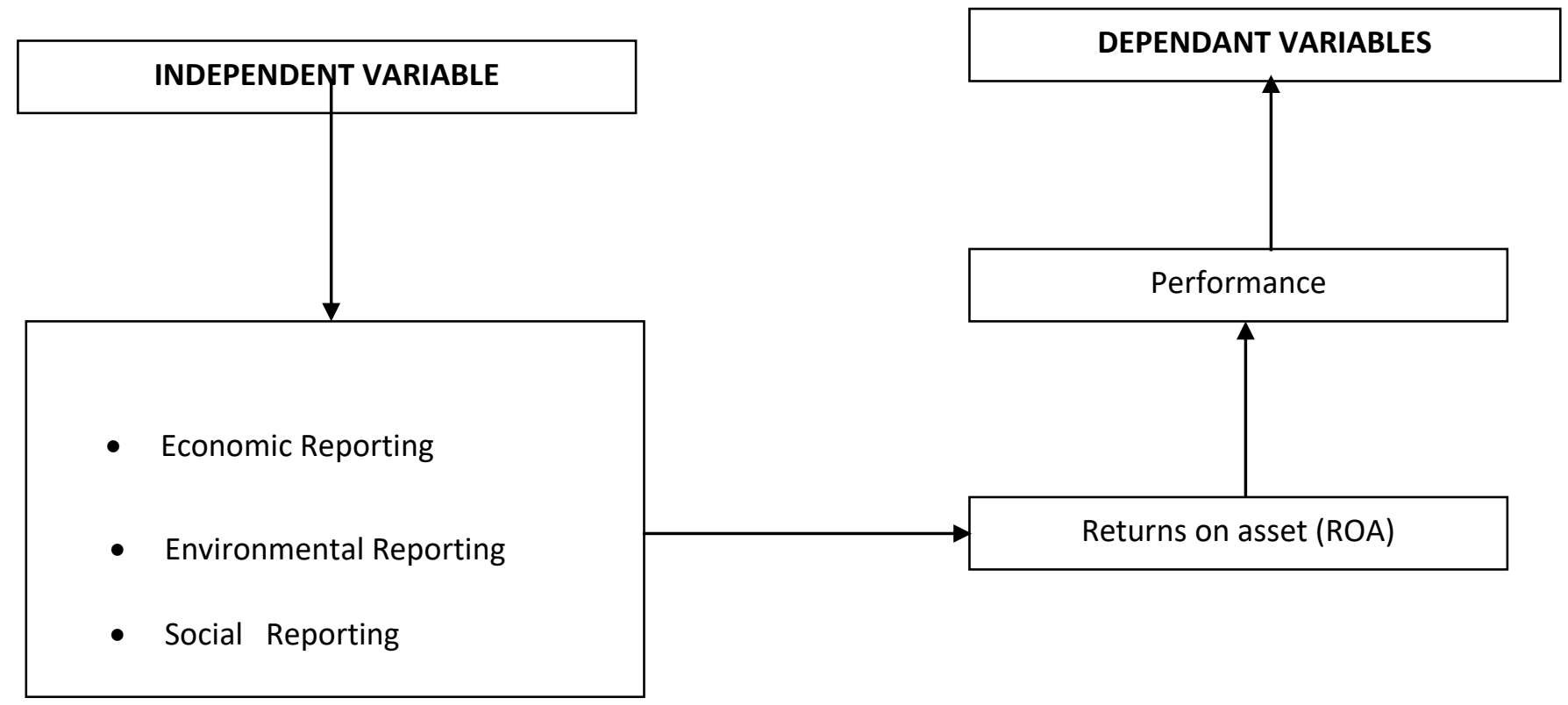

Figure 1: Conceptual model of co-integrated reporting bottom lines crystallization with returns on assets.

\subsection{Methodology}

The ex-post facto research design was employed in this study, which used historical data obtained from the annual reports and accounts of the studied listed hydrocarbon firms from 2010 to 2019. This study considered the twelve Nigerian-listed hydrocarbon firms on the Stock Exchange. The ordinary least square estimation method of the multiple linear regression model 
was employed to co-integrate the crystallization consequences of the triple bottom line constructs with the performance construct of the studied companies.

Secondary data were employed in this research, as the needed data already existed and was readily available from the identified sources. For this work, data were extracted from the published annual reports of firms studied. The multiple regression techniques were used in analyzing the treated data obtained for this study with the aid of SPSS version 22.0.

The measurement Models for this study are given as:

Corporate Performance $(\mathrm{CP})=f($ Sustainability Reporting-SR $)$.

$\mathrm{CP}(\mathrm{ROA})=f \mathrm{SR}(\mathrm{ECO}, \mathrm{ENV}, \mathrm{SOC})$

ROAit $=\beta 0+\beta 1$ ECODISit $+\beta 2$ ENVIDISit $+\beta 3$ SOCIDIS it $+\mu$ it

\section{Where:}

$\beta 0=$ Regression constant/Intercept term

$\beta 1, \beta 2, \beta 3=$ Coefficients of triple bottom line parameters

$\mu=$ Stochastic/error term

$\mathrm{i}=$ individual firm/corporation

$\mathrm{t}=$ time consideration.

\subsection{Findings and Results}

Table 1

STANDARDIZED

COEFFICIENTS

\section{Beta}

(CONSTANT)

ECONOMIC PERF. DISC.

ENVIRONMENTAL

DISC.
$-.008$

.065

PERF. - .043
$\mathbf{T}$

SIG

$-.206$

.853

.451

.667

$-.311$

.754 
SOCIAL PERF. DISC.

Sustainability reporting proxies' crystallization with returns on assets

The coefficients of the explanatory variables for economic, environmental, and social performance disclosures are $0.065,-0.043$, and 0.302 respectively. The regression crystallization line is given as: ROAit $=-.008+0.065$ ECODISit -0.043 ENVIDISit +0.302 SOCIDISit $+\mu$ it. This equation shows that there are both negative and positive crystallization consequences of triple bottom reports on the financial outcomes of the studied hydrocarbon companies, i.e. $[\beta=.302 ; p=.009]$. The beta values display the level of influence of the independent variables on the dependent variable.

Table 2

Crystallization of economic performance disclosures with Returns on Assets.

\begin{tabular}{llll}
\hline & Standard Coefficient & $\mathrm{t}$ & Sig. \\
\hline Beta & & \\
\hline (Constant) & -.008 & -.206 & .853 \\
\hline Economic Perf. Disc. & .065 & .451 & .667 \\
\hline
\end{tabular}

The beta weight $[\beta=.065 ; \mathrm{p}=.667]$ shows that there is an insignificant positive crystallization influence of economic performance disclosure construct with the returns on assets. The outcome shows that economic performance disclosure crystallized with the returns on assets up to $6.5 \%$. For every increase in economic performance disclosure, there is a positive crystallization of the returns on assets amounting to $6.5 \%$. Therefore, it could be inferred that economic performance 
disclosure has a positive crystallization influence on the financial performance of the studied companies.

Table 3

Crystallization of environmental performance disclosures with Returns on Assets

\begin{tabular}{llcc}
\hline & Standard Coefficient & $\mathrm{t}$ & Sig. \\
\hline & Beta & & \\
\hline (Constant) & -.008 & -.206 & .853 \\
\hline Environmental Perf. Disc. & -.043 & -.311 & .754 \\
\hline
\end{tabular}

The beta $(\beta)$ coefficient of environmental disclosure is -0.043 , which establishes that there is a non-significant negative crystallization influence of environmental performance disclosures with the returns on assets of the studied companies $[\beta=-0.043 ; p=.754]$. The result shows that Environmental performance disclosure crystalizes negatively with returns on assets, reducing it to $4 \%$ at every event of environmental disclosure, (i.e. -0.043). For every rise in environmental performance disclosure, there is a decline in the returns on assets.

\section{Table 4}

Crystallization of Social performance disclosures with Returns on Assets.

\begin{tabular}{llll}
\hline & Standard Coefficient & $\mathrm{t}$ & Sig. \\
\hline Beta & & \\
\hline (Constant) & -.008 & -.206 & .853 \\
\hline Social Perf. Disc. & .302 & 2.44 & .009 \\
\hline
\end{tabular}


The coefficient of the explanatory variable of SOCIDISit is 0.302 . The effect from the social performance disclosure of the study is thus; $[\beta=.302 ; \mathrm{p}=.009]$. This equation shows that there is a significant positive crystallization influence of social performance disclosure with returns on assets $[\beta=.302 ; \mathrm{p}=.009]$. The outcome shows that social performance disclosure crystalizes with and influenced returns on assets to the degree of $30.2 \%$ (i.e. 0.302). It is therefore concluded that social performance disclosure has a very near-significant but positive crystalizing influence on a firm's performance.

\subsection{Discussions}

The findings of the study show that there is a non-significant positive crystalizing influence of economic performance disclosure with the returns on assets of the studied quoted hydrocarbon companies in Nigeria. It shows economic performance disclosure crystalizing $6.5 \%$ with returns on assets of the studied companies. Environmental performance disclosure crystallizes negatively with the returns on assets, with a negative co-integration impact of $4.3 \%$. This result shows that for every rise in environmental disclosure, there is an adverse crystallization influence on the returns on assets of the quoted oil and gas companies by $4.3 \%$. Lastly, social performance disclosure shows a significant positive crystallizing impact on the returns on assets of the studied companies. This is explained at $30.2 \%$, which means social performance disclosure has a significant crystallizing influence on the returns on assets of the studied hydrocarbon companies.

On the aggregate, the outcome of the findings shows both positive and negative crystallizing impact of triple bottom reporting constructs on the performance of hydrocarbon companies in Nigeria, taking into consideration the returns on the asset. This finding agrees with Effiong, et al, (2019) whose study posited that social and environmental disclosure has a positive and 
significant effect on returns on assets of corporate organizations. The findings also agree with the study by Effiong, et al, (2017) whose work shows a positive relationship of triple bottom line costs reporting with cost-benefit optimization.

This study found out that economic performance disclosures of the studied firms have a nonsignificant crystallizing effect on their performance indicator, and that environmental performance disclosures have a non-significant crystallizing influence on the performance of the listed companies. The result also shows a near-significant but positive co-integral crystallization between social performance disclosures and the performance indicator of the studied companies. This result corroborates the findings of Oti, Effiong \& Akpan, (2017), who posited that social and environmental disclosures have a positive effect on ROA. This study however deviates from their findings on social performance because their result showed a non-significant relationship between social disclosures and returns on assets.

\section{Conclusion}

There exist a positive co-integral crystallization link between triple bottom line constructs and financial performance indicators of firms operating in the hydrocarbon sector of the Nigerian economy. Sustainability reports significantly crystallize the financial fortunes of companies adopting and following the sustainability reporting framework. However, findings show that some firms are environmentally friendly even before the adoption of the Sustainable Development Goals guidelines in Nigeria. Hydrocarbon companies and environmentally exposed companies are paying much attention to reporting sustainability. However, most firms are still behind on this trend. With the implementation of sustainability guidelines and mandatory reporting by listed firms in the petroleum industry in Nigeria, it is believed that there will be a better sustainable environment. 


\section{Recommendations}

The following recommendations are made to enhance sustainability reporting, based on the outcome of the study: Firms should be encouraged to disclose information on a triple bottom line basis as this will enhance their performance; With the implementation of sustainability reporting guidelines, and the mandatory disclosure by listed Nigerian firms, there should be a means for rewarding firms that live up to their environmental and social responsibilities, while defaulters should be sanctioned.

\section{REFERENCES}

Atu, O. \& Osaretin, K. (2016). Triple Bottom Line Accounting: A Conceptual Expose. IOSR Journal of Business and Management (IOSR-JBM), 13(4), 30-36

Brundtland, G. H. (1987). Our Common Future. United Nations World Commission on Environment and Development (Brundtland Commission). Oxford: Oxford University Press. ISBN: 019282080X

Chikwendu, O.U., Okafor, G.O., \& Jesuwunmi, C.D.A (2019). Effect of sustainability reporting on Nigerian listed companies' performance. Canadian Contemporary Research Journal, 1(1), 96-111.

Deegan, C., (2018): The legitimizing effect of social and environmental disclosure: a theoretical foundation, Accounting, Auditing and Accountability Journal, 4 (1), 32-38.

Dowling, J. \& Pfeffer, J. (1975). Organizational legitimacy, societal values, and organizational behavior. Pacific Sociological Review, 18(1), 122-136.

Effiong, S. A., Okare, O. M., and Udama, D. U. (2017).Triple bottom line costs reporting and environmental/social restiveness: an empirical evaluation of applicability benefits to Oil \& Gas companies in optimizing corporate image in the Niger Delta Region of Nigeria. Journal of Economics and Sustainable Development, 8(14), 244 - 253.

Effiong, S. A., Oti, P. A. and Akpan, D. C. (2019). Triple bottom line reporting and shareholders' value in oil and gas marketing firms in Nigeria. Academy of Accounting and Financial Studies Journal, 23(5), 1-16.

Elkington, J. (2004). Enter the triple bottom line. The triple bottom line: Does it all add up? a theoretical foundation, Accounting, Auditing and Accountability Journal, Vol. 4 (1), 32-38.

Freeman, E.R. (2009). Strategic management: a stakeholder approach. Business and Public Policy Series. Pitman Series in Business and Public Policy. 276. ISBN: 0273019139. 
GRI (2015). Sustainability Reporting Guidelines: G3.1 version, retrieved from http://globalreporting.org on 18th May 2021.

Hong, Y.C., Fabio, G., \& Thiago, H.T. (2014). Scoring sustainability reports using GRI indicators: a study based on ISE and FTSE4Good price indexes. Journal of Management Research, 6(5), 23-35.

Oti, P.A., Effiong, S. A., \& Arzizeh, T. (2012). Environmental costs and its implication on the returns on investment: an evaluation of selected manufacturing companies in Nigeria. Global Journal of Management and Business Research, 12(7), ver 1.0, 35 - 51.

Oti, P. A., Effiong, S. A., \& Akpan, D. C. (2017). Accounting perspective of the environmental footprint of oil and gas industry in the South-South region of Nigeria. Journal of Accounting and Financial Management, 3(3), 1-11.

Ijeoma, N. B. (2014). Assessing the impact of the triple bottom line reporting on the problem of corporate sustainability in Nigeria. American Journal of Service Science and Management. 1(1), 10-16.

Isa, M. A. (2014). Sustainability reporting among Nigeria food and beverages firms. International Journal of Agriculture and Economic Development, 2(1), 1-9.

Uwuigbe, U. \& Uadiale, O. M. (2018). Corporate social and environmental disclosure in Nigeria: a comparative study of the building material and brewery industry. International Journal of Business Management, 6(2), 258-264. 